\title{
Cooperative Learning Model and Thinking Style at Madrasah Tsanawiah Bina Ulama Kisaran
}

\author{
Dwi Pratiwi \\ Postgraduate Program of State University of Medan \\ State University of Medan \\ Medan, Indonesia \\ dwidwipratiwi@gmail.com
}

\author{
Julaga Situmorang, Derlina \\ Postgraduate Program of State University of Medan \\ State University of Medan \\ Medan, Indonesia
}

\begin{abstract}
An abstract is a brief summary of to analyze: (1) Comparison of students physics learning outcomes learned by cooperative learning model of Think Pair Share with cooperative learning model Two Stay Two Stray (2) Comparison of students physics learning outcomes that have random thinking style and sequential thinking style (3) interaction between models cooperative learning Think Pair Share and thinking style to student physics learning outcomes. This research is a quasi experimental research with post test only control group design. Population This research is the students of class VII Madrasah Tsanawiah Bina Ulama Kisaran. The sample selection was done by cluster random sampling. The sample is divided into two classes, the experimental class taught by the Think Pair Share learning model and the control class is taught with Two Stay Two Stray learning model. The data in this study were analyzed by two-way ANAVA. The result of the research shows that: (1) The result of student physics learning which is taught by cooperative learning model of Think Pair Share is higher than the cooperative learning model of Two Stay Two Stray (2) The result of student physics learning which has random thinking is higher than sequential thinking (3) interaction between cooperative learning model Think Pair Share and thinking style to student physics learning result.
\end{abstract}

Keywords: Cooperative Learning, Think Pair Share, Two Stay Two Stray, Thinking Style, The Result of Physics Learning

\section{INTRODUCTION}

The development of science and technology today requires everyone to improve themselves and increase their potential. One way that can be done to be able to fix themselves is through education. Education is one of the basic needs for humans that are needed in living life. Education has a very strategic role in improving the quality of human resources and efforts to realize the ideals of the Indonesian people in realizing general welfare and intellectual life of the nation. Science (science) education is one aspect of education that is used as a tool to achieve educational goals. According to Departemen Pendidikan Nasional (2003) states that science education does not only consist of facts, concepts and theories that can be memorized, but also consists of active activities or processes using scientific thoughts and attitudes in studying natural phenomena that have not been explained. As part of science (science), physics has a large contribution in science and technology, because physics has a knowledge structure obtained through proven methods.

Based on preliminary observations that researchers did in one of the MTs showed that physics learning was still dominant in providing information by lecturing and communication in one direction. The results of interviews with teachers in the field of physics study found that student learning outcomes were still below standard, where only $46 \%$ of students had a score of $\geq 60$, while $54 \%$ of students had a score of $<60$. This percentage is obtained from the list of MID semester grades and daily tests.

The description shows that learning takes place by applying conventional learning. This is in line with the problems in the research of Khalid and Azeem (2012) that learning at the university level is also still used to using learning that emphasizes the explanation of theory and memorization that characterize the application of traditional learning. A learning that is no longer conventional is needed. Where science teachers especially physics must be demanded in designing a learning model that can create a learning atmosphere that is able to increase student activity in the classroom. This is in line with Sharma's (2016) study which found that a classroom environment is needed that supports students where they can create their own ideas; both individually and collaboratively. For this reason, a learning model is needed that can have an impact on students' thinking abilities. This is also in line with the results of Poonam's (2017) study which concluded that innovation in learning was very important. The teacher must help students meet life's challenges, fully \& make students confident. New demands and new visions provide more innovative strategies such as: constructivist approaches, activity-based methods, smart classes, overseas visits and CCE that are very helpful to make classroom interactions very effective.

Think pair share learning model is a suitable model chosen to overcome this. Dol \& Halkude (2017) concludes that Think Pair Share is active learning that is famous for a strategy in which students work on the problems posed by the teacher, first individually (Thinking), then in pairs (Couples) and finally with the whole class (Share). The application of Think Pair Share Learning Model can train students to think and exchange opinions with friends or classmates, so that they can 
improve learning outcomes of students' cognitive domains and learning outcomes. This is supported by the Alpusari \& Putra research (2013) which in his research concluded that after applying the TPS type cooperative learning model, there was an increase in the overall student independence so that it could develop and have an impact on increasing students' mastery of concepts and able to create curiosity in students

This is in line with the research conducted by Ofodu \& Lawal (2007) concluding that TPS type cooperative learning can effectively improve learning outcomes compared to conventional learning. The experimental group students not only learned better but the level of proficiency was also higher than the control group. There is also Raba (2017) which in his research concluded that the think-pair-share strategy plays a positive role in improving students 'oral communication skills, creating a cooperative learning environment, increasing students' motivation to learn better and increasing interaction among students. In fact, it creates a pleasant learning environment and increases motivation among students

In addition to learning models there are several other things that must be examined to improve the quality of students' thinking. Among them is the style of thinking. Based on the results of interviews also obtained data that the teacher does not consider the thinking style of students. The teacher considers the style of thinking of each student is the same. Even though the teacher should pay attention to students 'thinking style so that students' creativity in learning can be more developed. The style of thinking is divided into two types, namely sequential and abstract thinking styles. This can be in accordance with Setiawan \& Rahman's (2013) research which states that students' thinking styles consist of two types, namely sequential and random. Style relates to how a person likes to use his ability to do something so that automatically thinking styles can affect learning outcomes

This is similar to the results of Depary's (2013) study which also states that students' thinking styles can influence learning outcomes in physics learning. Likewise, the results of other studies conducted by Hanim (2016) found that there are differences between abstract abstract thinking styles with random sequential. Concrete sequential thinking styles get the average learning outcomes in Indonesian language learning due to the concrete sequential styles that pay attention and remember reality with easy and easy to remember facts, information, formulas and rules.

\section{REVIEW OF THE LITERATURE}

\section{Physic learning outcomes}

Learning outcomes are the result of an interaction of learning actions and teaching actions that are seen from individual changes that cover the cognitive, affective, and psychomotor fields (Trianto, 2010). Physics is the building of knowledge that describes the efforts, findings, insights and wisdom that are collective from humanity (Wartono, 2003: 18). More than that according to Collette and Chiappetta (1994), science is a way of thinking (affective), a way of investigating (proczess), and a body of knowledge. Based on the synthesis above, the results of physics learning are the result of an interaction between learning and teaching acts that can be seen from individual changes in describing facts, concepts, principles, laws, postulates, and theories inherent in the development of natural science.

\section{Thingking style}

According to Gregorc (Deporter, 2009) the style of thinking is a thought process that combines how the mind receives information and regulates that information in the brain. Whereas according to Sternberg (Santrock, 2004) the style of thinking is the way a person chooses to use his abilities. While Taylor et al (1977: 55) defines the style of thinking as a process of drawing conclusions (Thinking is inferring process). So it can be concluded that the style of thinking is the way a person chooses to combine how the mind receives information and organizes information as a process of drawing conclusions.

\section{Sequential Thinking Style}

Sequential thinking style is a way of thinking that is more dominant using the right brain in regulating information in the thinking process carried out linearly or step by step Gregorc (Deporter, 2009). Sequential thinking style is divided into two abstract concrete and sequential sequences and their elaboration.

\section{a. Concrete Sequential thinking style (SK).}

The term for concrete sequential thinkers is structured thinkers (PT). He also added that this perfectionist thinker is oriented to detail and learning while doing. PT is good with dates, facts, formulas and lists. Sequential Abstract thinking style (SA) DePorter (2009: 49) gave a new term for people who have a Sequential Abstract (SA) thinking style, namely Exploration Thinker (PE). He added that these thinkers are more experimental, more creative, and open to intuitive jumps.

\section{Random Thinking Style}

Random thinking style is the dominant way of thinking using the left brain in managing information which in the process of thinking is done by passing the steps in a procedure but still produces what is desired Gregorc (Deporter, 2009). Random Thinking Style can also be divided into two: concrete random thinking style and abstract random thinking style.

\section{a. Concrete Random Thinking (AK)}

DePorter (2009: 50) gives a new term for people who have a Concrete Randomized (AK) thinking style, namely Logical Thinkers (PL). He added that these thinkers preferred to analyze so they were very good at doing research because they could find important ideas and information, especially if well organized. They think logically and rationally and ask questions to find out why, and how things are behind.

\section{b. Random Abstract Thinking Style (AA)}

DePorter (2009: 49) gives a new term for people who have a Random Abstract (AA) style of thinking that is Flexible Thinkers (PF). He added that before making a decision or forming an opinion, this thinker needs time to reflect and absorb new information and want to see the whole picture before going into details.

\section{Cooperative Learning Model}


Lie (2007) cooperative learning model (cooperative learning) with the term learning mutual cooperation, is a learning system that provides opportunities for students to work with other students in structured tasks. While Slavin (2009) argues that "In cooperative learning methods, students work together in four members teams to master material initially presented by the teacher". Next Trianto (2011: 54) defines "cooperative learning model is a broader concept covering all types Group work includes teacher-led forms or directed by the teacher. So it can be concluded that cooperative learning is a learning model where the learning and working systems provide opportunities for students to work together with other students in structured tasks led by the teacher or directed by the teacher.

\section{Think Pair Share}

Slavin (2009) states that Think Pair Share (TPS) is a learning model that allows students to collaborate in small groups with stages of thinking, pairing, and sharing. TPS type cooperative learning model is based on constructivism learning theory. Constructivism theory states that students must find their own and transform complex information, check new information with old rules and revise it if the rules are no longer appropriate. TPS teaching and learning techniques have the following benefits: (1) Easy to implement in a class large, (2) Give students time to reflect on the contents of the subject matter, (3) Students are trained to express opinions before sharing with small groups or classes as a whole, (4) Optimizing student participation, namely giving each student eight times more opportunities to recognized and showed their participation to others (Isjoni, 2011: 112)

\section{Two Stay Two Stray}

The two stay two stray learning model is a learning model where students learn to solve problems with group members, then two students from the group exchange information on the two other members of the group who live Lie (2010: 61). The characteristics of the TSTS learning model according to Lie (2010: 62) are (a) students work in groups cooperatively to complete learning material, (b) groups are formed from students who have high, medium and low abilities, (c) if possible members groups come from different races, cultures, ethnicities, genders and (d) awards are more group-oriented than individuals. The two structure only has two guests giving the group the opportunity to share the results and information with other groups by: 1 . Students work together in groups of four as usual. 2. When finished, two people from each group will leave the group and each visit another group. 3. Two people who live in groups are tasked with sharing their work and information with their guests. 4. Guests ask themselves and return to their own groups and report their findings from other groups. 5. Match groups and discuss the results of their work.

\section{METHODOLOGY}

This research was carried out at MTs BINA ULAMA. The study was carried out in August 2018 second semester T.P $2018 / 2019$ in class VII as many as 6 meetings. The population of this research is all seventh grade students at MTs BINA ULAMA in 2018/2019 Academic Year consisting of 5 classes. The sample in this study consisted of two classes namely class
VII-B totaling 40 students as an experimental class, and class VII-C totaling 40 students as a control class. The experimental class and control class are taken by Cluster Random Sampling technique, which is the technique of taking samples from the population randomly without regard to the strata in the population. The variables in this study are Think Pair Share cooperative learning models and Two Stay Two Stray learning models as independent variables, students 'physics learning outcomes as dependent variables and students' thinking style as moderator variables. The research design was done by Postes Only Control Group Design and can be seen in table 3.1

TABLE 3.1 Design of Student Learning

\begin{tabular}{|c|c|c|}
\hline Class & Treatment & Postes \\
\hline Eksperiment & $\mathrm{X}$ & $\mathrm{T}_{1}$ \\
\hline Control & $\mathrm{Y}$ & $\mathrm{T}_{1}$ \\
\hline
\end{tabular}

Information:

$\mathrm{X}=$ Treatment in the experimental class is the application of Think Pair Share models

$\mathrm{Y}=$ Treatment in the control class is the application of the Two Stay Two Stray learning model

$\mathrm{T} 1=$ Postes in the experimental class and control after treatment

To observe students' thinking style that is after students are grouped based on the type of thinking style, then the students will have sequential and random thinking styles. The research design used is factorial design $2 \times 2$, which compares TPS cooperative learning models and TSTS learning models to random and sequential thinking styles. The instrument in this study was to use 20 multiple choice test questions to measure learning outcomes, questionnaires to detect thinking styles and interview sheets as a preliminary study. Hypothesis testing using two-way variance analysis technique $(2 \times 4$ factorial design) with a significant level of $5 \%$.

\section{RESEARCH AND CONCLUSION}

From the results of the analysis calculation about the difference in physics learning outcomes students who are taught with TPS models are $\bar{X}_{=} 23.55$ and TSTS models learning $\bar{X}=22.42$, obtained the calculation result of $F$ is 12 , 69 and the Ft table price is 3,97. With according to research findings concluded, that the research hypothesis which states: physics learning outcomes students taught with TPS models higher than the results of studying physics students taught by the model TSTS learning at the level confidence $\alpha=0,05$ has been tested the truth.

The results of the analysis of variance analysisabout the difference in physics learning outcomes between students who have a thinking style sequential and thinking style random sequential with an average of $\overline{\bar{X}}=22,84$ and $\overline{\bar{X}}=21,22$. Based on the Table 4.16 can be calculated $\mathrm{Fh}=13.21$ and price table for $\alpha=0.05$ with $\mathrm{dk}$ (1) obtained $\mathrm{Ft}=3,97$ so it canstated $\mathrm{Fh}$ $(13,21)>$ Ft $(3,97)$. students who have a thinking style sequential at the level of trust $\alpha=0,05$ the truth has been tested 
Results of Calculation of Interaction Between Models Learning and Thinking Style Against Student Physics Learning Outcomes done with Factorial 2 × 2 ANOVA obtained results Fh calculation $=45,75$ with table price Ft for the confidence level $(\alpha)$ of 0.05 with $\mathrm{dk}=1$ is $\mathrm{Ft}=3,97$ so it can be stated $\mathrm{Fh}$ $(45,75)>$ Ft $(3,97)$, thus can concluded the hypothesis statement research which states: there interaction between learning models and style of thinking towards the results of learning physics students have tested the truth at the level significant $\alpha=0,05$

\section{REFERENCES}

[1] Alpusari, M. \& Putra, R.A. (2015) . The Application of Cooperative Learning Think Pair share (TPS) Model to Increase the Process Science Skills in Class IV Elementry School Number 81 Pekan Baru City. International Journal of Science and Research (IJSR). Vol $4: 2319$. 7064

[2] Departemen Pendidikan Nasional. (2003). Undang-Undang Republik Indonesia No. 20 Tentang Sistem Pendidikan Nasional. Jakarta: Departemen Pendidikan Nasional Republik Indonesia.

[3] Depary, S. (2013). Model pembelajaran dan Gaya berpikir terhadap hasil belajar fisika. Jurnal Teknologi Pendidikan, Vol.6. No. 1: 979 6692

[4] DePorter, Bobbi dan Mike Hernacki. (2009). Quatum Teaching. Bandung : Kaifa

[5] Dol, S.M. \& Halkude, S.A. ( 2017).An EffectiveWay to Improve Problem Solving Skill using TPS, T24S and T21S: A Comparative Study. Journal of Engineering Education Transformations. Volume 30,. No. 3, : 2394-1707

[6] Hanim, S.A. \& Ashari, K. (2016). Pengaruh strategi pembelajaran dan gaya berpikir terhadap hasil belajar bahasa indonesia siswa. Jurnal Teknologi Pendidikan. Vol. 8. No. 2 : 2407-7437

[7] Isjoni. (2011). Pembelajaran Kooperatif Meningkatkan Kecerdasan Komunikasi Antar Peserta Didik, Pustaka Belajar, Yogyakarta.

[8] Khalid, A. \& Azeem, M. (2012). Constructivist Vs Traditional : Effective Instructional Approach in Teacher Education. International Journal of Humanities and Social Science. 2 (5) : 170-177

[9] Lie, A. (2007).Cooperatif Learning, Grasindo, Jakarta.

[10] Ofodu, G. O. \& Lawal, R. A. (2011). Cooperative Instructional Strategies and Performance Levels of Students in Reading Comprehension. International Journal of Emerging Sciences. Vol. 3 No. 2: 103-107.

[11] Poonam, Sarita. (2017). The use of innovative strategies to enhance quality of classroom interaction. International Journal of Advanced Research and Development. Volume 2; Issue 4; Page No. 137-141 : $2455-4030$

[12] Santrock JW. (2004). Psikologi Pendidikan Edisi Kedua. Jakarta: Kencana Prenada Media Group

[13] Sharma,H.L \& Poonam. (2016). Constructivist Approach for Teaching English: Making sense of Paradigm shift from the Traditional Approach. International Journal of Science and Research (IJSR).; 5(10): 788-792.

[14] Slavin. (2009).Cooperative Learning. Nusa Media, Bandung.

[15] Taylor C, Lillis C, Le More P. (2000). Fundamentals of nursing the art and science of nursing care B. Third Edition. Philadhelpia: Lippincott

[16] Trianto. (2011).Mendesain Model Pembelajaran Inovatif-Progresif, Kencana, Jakarta.

[17] Wartono. (2003). Strategi Belajar Mengajar Fisika. Malang: JICA 